\title{
Sustainable development: Using stone dust to replace a part of sand in concrete mixture
}

\author{
Gidion Turuallo ${ }^{1 *}$,Harun Mallisa ${ }^{1}$, and Nicodemus Rupang ${ }^{1}$ \\ ${ }^{1}$ Lecturer in Civil Engineering Department, Tadulako University Palu, Indonesia.
}

\begin{abstract}
Stone dust is a waste material produced in stone crusher industry. Stone dust produced from the crushed stone industry is quite numerous. PT Mega Beton Jaya is a stone crushed industry, which is located in Buluri, Palu, has difficulty in providing a location to accommodate the waste of stone dust. In addition, the community around this industry is quite worried with the waste ash as the air around the industry contaminated with the stone ash. This study aims to find out the maximum percentage of stone dust to substitute sand in a concrete mix to obtain the maximum strength and good workability. The cement used throughout this work was Portland cement composite (PCC) produced by PT Semen Tonasa, the sand was taken from Palu river, while the stone dust and coarse aggregate were taken from PT Mega Beton Jaya stone crushed industry. The percentages of stone dust replacing sand were varied from $0,20,30,40,60,80$ and $100 \%$ to find out the maximum percentage of stone dust to replace sand from river to produce the maximum compressive strength of concrete. The results of this research showed that the maximum percentage of stone dust, which could replace river sand in concrete mixture was $40 \%$ with the strength $15 \%$ higher than that of concrete with natural sand only. The higher the percentages of stone dust, which were used to replace a part of sand in concrete mixtures resulted the lower slump of concrete. In addition, the replacing natural sand with stone dust higher than $20 \%$ produced the value of slump for both normal and high strength concretes lower than those concretes with natural sand only.
\end{abstract}

\section{Introduction}

The term of sustainable development is defined as the development that meets the needs of the present generation without compromising the ability of future generations to meet their own needs. The aims of sustainable development is improving the quality of life, supports the use of energy and natural resources in means that confirms long-term survival of human life [1-6].

Nowadays, concrete is the most widely used as one of the construction materials in the world as well as in Indonesia. The increasing of infrastructure facilities will cause increasing in the need of concrete as construction material. The main constituent of concrete is aggregates that are usually taken from natural ingredients. Sand or fine aggregate in generally is taken from river, which is the most material consumed after coarse aggregate in producing

* Corresponding author: turuallo@yahoo.co.uk 
concrete. Therefore, construction industries should find out alternative materials to replace the demand of sand in construction industry for sustainable development reason. The use of waste materials as by product from industries such as stone dust to replace natural sand in concrete can give some benefits such as reduction in cost of concrete production [7], as well as it can reduce environmental problem due to the increasing of stone dust waste [8]. The stone crusher industry of PT Mega Beton Jaya has three stone crusher machines with an average production per machine can reach $150 \mathrm{~m}^{3}$ per day. The company found difficulties in providing area, which was large enough for disposal, as shown in Figure 1 below:
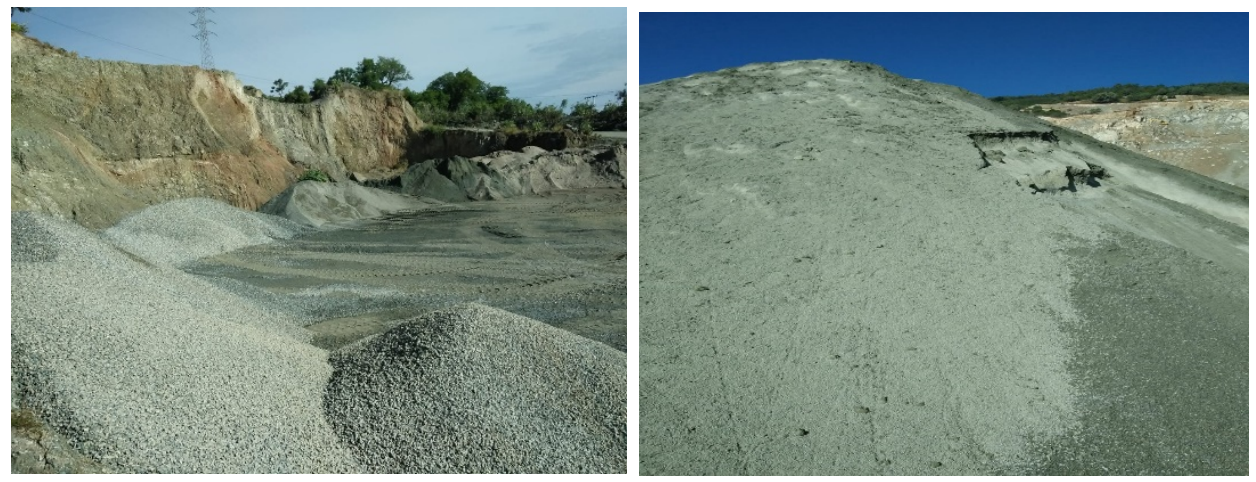

Fig. 1. Stone dust produced by PT Mega Beton Jaya Palu.

In addition, the stone dust produced from the stone crusher industry caused serious problems for the surrounding community because it has been causing air pollution. Therefore, utilising this stone dust in concrete mixture can solve the social problem i.e. the environmental impact happened around the stone crusher industry.

The waste material resulted from stone crushed industry creates problems both on the part of industry and the surrounding community. The stone crushed industry of PT Mega Beton Jaya experienced difficulties in providing land that was large enough to accommodate rock ash waste produced from their stone crushed industry. The company has three stone crusher machines with an average production per machine can reach $150 \mathrm{~m}^{3}$ per day as shown in Figure 1 above.

The need for concrete as a construction material is increasing rapidly in various regions in Indonesia, especially the needs in Palu after the earthquake on September 28, 2018 last year. As a result, the use of primary materials for concrete such as sand also increases. Therefore, efforts should be made to replace a part of this material so that this natural material is not used up in future, for sustainable development program reason.

\section{Stone dust as a part replacement material of sand in concrete}

Many researchers have done researches to find out the effect of stone dust to replace part of sand in concrete mixture [9-15]. Sankh at all [15] found that many alternative materials such as copper slag, ground granulated blast furnage slag (ggbs), washed bottom ash, quarry dust foundry sand, etc., which could replace natural sand in concrete. They found that replacing sand by quarry dust could improve the compressive strength of concrete. However, the use of quarry dust could decrease the workability of concrete produced, due to absorption of added water by the quarry dust. Therefore, they suggested using quarry dust between 55 to $75 \%$. Furthermore, they suggested for the $100 \%$ replacement of sand could be applied by 
adding of fly ash to replace some cement along with quarry dust or stone dust to replace part of sand in concrete.

Suman at all.[12] concluded in their work that at the maximum replacement level of sand by stone dust was $60 \%$, to attain the maximum compressive strength of concrete. It could be achieved by using superplastizicier with dose of $1-1.5 \%$ by cementitious materials weight. This is similar to the results of work, which was done by Srivastava [13]. He added that by replacing natural sand by $8-100 \%$ of stone dust could improve the compressive strength of concrete between $8-27 \%$. The effect of stone dust, when it was used as substituting of natural sand in concrete to durability of concrete; was reported by Shanmugapriya at all. [16]. They found that the electric current through to concrete reduces by increasing of the stone dust in concrete mixtures at the age of 28 and 90 days. This meant that the chloride ion permeability is very low and that will increase durability of the concrete.

\section{Experimental works}

\subsection{Materials}

A single batch of sand, coarse aggregate, PCC cement, and stone dust were used throughout the experimental work. The PCC cement was produced by PT Semen Tonasa, which was PPC Type I cement with the specific gravity of 3.1. Both coarse and fine aggregates were tested in laboratory before they were used in concrete, to check whether all the materials meet the requirements to be used in concrete mixture. The sand was fine sand taken from Palu River. The coarse aggregate that was crushed aggregate and stone dust were taken from Stone Crushed Manufacture of PT Beton Jaya Palu. The nominal sizes of coarse aggregate were ranged from 5 to $20 \mathrm{~mm}$. The fine and coarse aggregates were in air dry conditions; therefore, some water was added for absorption to allow both of them meet their saturated service dry (SSD) condition. The used superplasticizer was Type Naptha 511P.

\subsection{Mix proportions}

There are two mix proportions of concrete with the w/c ratio of 0.50 and 0.25 for both normal and high strength concretes respectively. The mix proportions with the natural sand are presented in Table 1 below:

Table 1. Mixes proportion

\begin{tabular}{|c|c|c|c|}
\hline \multirow{2}{*}{ No } & \multirow{2}{*}{ Materials } & \multicolumn{2}{|c|}{ Type of concrete strength } \\
\cline { 3 - 4 } & & Normal strength (kg) & High strength (kg) \\
\hline 1 & Cement & 371 & 476 \\
\hline 2 & Sand & 761 & 676 \\
\hline 3 & Coarse aggregate & 1083 & 1257 \\
\hline 4 & Water & 185 & 136.4 \\
\hline 5 & Superplasticizer & - & 0.133 \\
\hline
\end{tabular}

Each grade of concrete consists of seven mixes regarding to the level of stone dust to replace natural sand in concrete i.e. $0,20,30,40,60,80$ and 100\%. Therefore, there were 14 concrete mixes for both normal and high strength concrete. 


\subsection{Specimens and testing}

To measure the compressive strength of concrete, three concrete cubes or specimens for each mix and testing date were prepared to be tested at ages 3, 7, 14,21, 28 and 56 days. Therefore, eighteen cubes of every mix should be prepared. The concrete cubes with the size of $150 \mathrm{~mm}$ X $150 \mathrm{~mm}$ X $150 \mathrm{~mm}$ were curing in water with the room temperature of $25{ }^{\circ} \mathrm{C}$.

\section{Results and discussions}

Table 2 below presents the slump values for each concrete mixture. It can be seen from the table below that using up to $20 \%$ of stone dust to replace some of sand in both normal and high strength concretes can increase the value of concrete slump of both the concretes. This is because stone dust is finer than natural sand, which produces concrete that is easier to flow.

Table 2. The Slump value of normal and high strength concrete

\begin{tabular}{|c|c|c|c|}
\hline \multirow{2}{*}{ No } & \multirow{2}{*}{ \% sand } & \multicolumn{2}{|c|}{ Slump value of concrete } \\
\cline { 3 - 4 } & $\begin{array}{c}\text { Normal strength } \\
\text { concrete (NSC) } \\
(\mathbf{m m})\end{array}$ & $\begin{array}{c}\text { High strength } \\
\text { concrete (HSC) } \\
(\mathbf{m m})\end{array}$ \\
\hline 1 & 100 & 70 & 48 \\
\hline 2 & 80 & 80 & 52 \\
\hline 3 & 60 & 68 & 47 \\
\hline 4 & 40 & 60 & 45 \\
\hline 5 & 30 & 55 & 40 \\
\hline 6 & 20 & 40 & 35 \\
\hline 7 & 0 & 30 & 28 \\
\hline
\end{tabular}

The use of stone dust above $20 \%$ can decrease slump of both the concretes. They are expected as the more stone dust in the concrete mixtures the more water absorbed; as the results the slump of the both concretes decrease. However, using the stone dust up to $60 \%$ still produced a good value of slump for both the concretes.

The compression strength of normal strength concrete (NSC) is shown in Fig. 2. below. The graph shows that the maximum percentage of stone dust that can replace sand in concrete mixture to produce the maximum strength is $60 \%$. with the strength at 28-days of 38.756 $\mathrm{MPa}$ or $10.73 \%$ higher than that of concrete with $100 \%$ sand (35.0 MPa). 


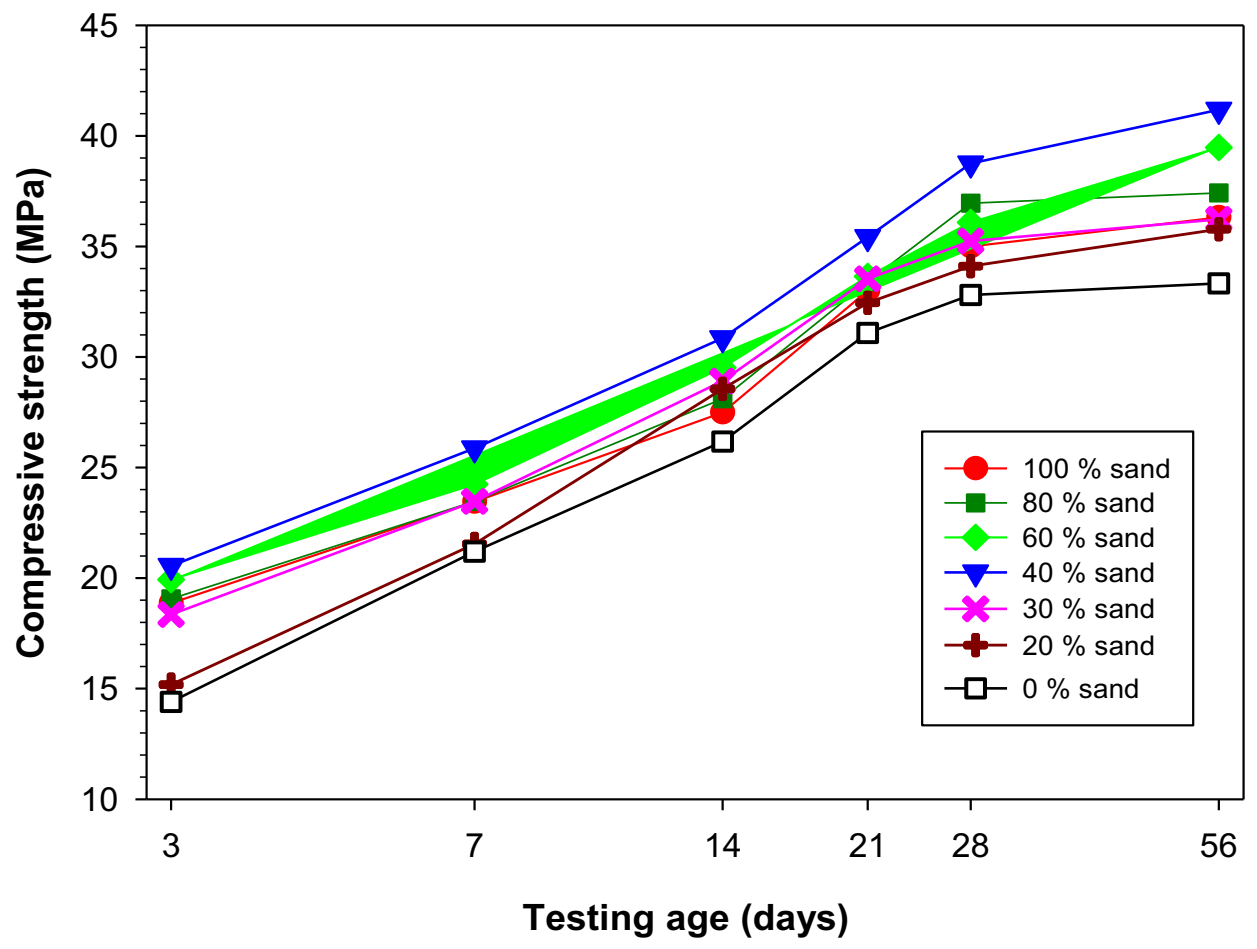

Fig. 2. Strength development of normal strength concrete

At age 56 days, the strength of concrete with 40 and $60 \%$ sand still significantly increased compared to other mixes. The strength of concrete was increased by $9.39 \%$ and $6.25 \%$ respectively to their strength at age 28 -days.

The strength development of high strength concrete (HSC) is shown in Fig. 3. below. Similar to the normal strength concrete, the maximum percentage of sand in the high strength concrete, which can be replaced by stone dust to result the maximum strength of concrete, is $60 \%$. The strength of concrete with $60 \%$ stone dust at age 28-days is $72.489 \mathrm{MPa}$ or $4.65 \%$ higher than that of concrete with $100 \%$ sand or sand only (69.267 MPa). At age 56-days, the strength of concrete with $60 \%$ of stone dust still increases. It increases by $2.15 \%$ to its strength at 28-days, while other concretes tend to constant or slightly increase after age of 28-days.

The increasing strength of concrete is expected as the stone dust contains $\mathrm{CaO}$ compounds, which is one of the main compounds of cement and contributes to the strength development of concrete. The maximum percentage of stone dust to replace sand in concrete mixture is $60 \%$. By replacing sand with stone dust higher than $60 \%$ results strength of concrete lower than that of concrete with sand only. It is expected as the result of some water prepared for cement hydration is absorbed by the stone dust; therefore, the available water for hydration process of cement is not enough. As the result the product of cement hydration, which is the main source of the concrete strength will decrease as well. 


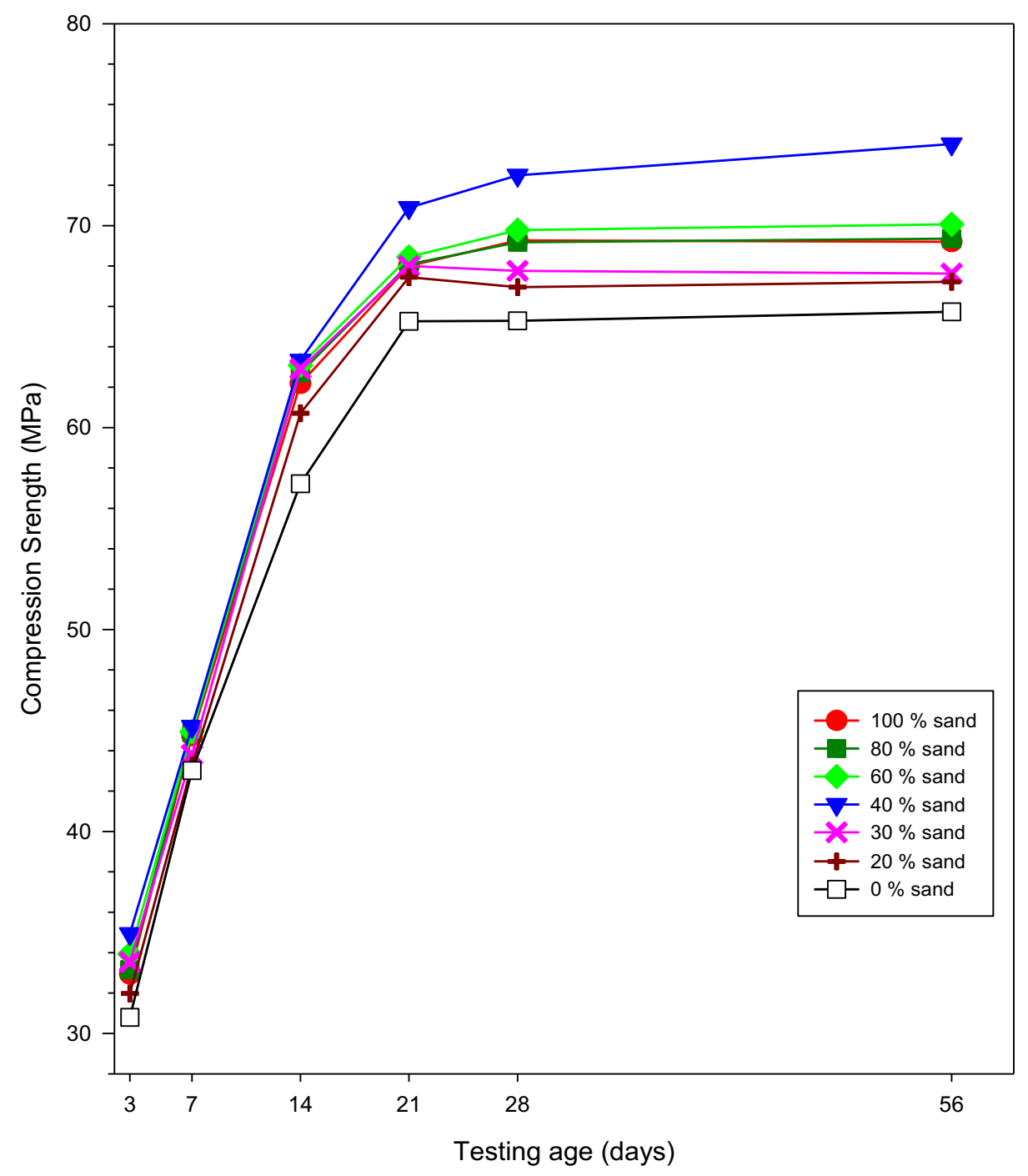

Fig. 3. Strength development of high strength concrete

\section{Conclusion}

The conclusion could be drawn as follow:

1. The maximum percentage of stone dust to replace sand in concrete mixture for both normal and high strength concrete is $60 \%$.

2. The strengths of concrete with $60 \%$ stone dust at age 28 -days are $38.756 \mathrm{MPa}$ and 72.489 $\mathrm{MPa}$ for normal and high strength concrete respectively. They are increased by $10.73 \%$ and $4.65 \%$ to concretes with $100 \%$ sand.

3. Replacing sand by stone dust above $70 \%$ results in strength of concrete lower than those concretes with $100 \%$ sand. It is due to some water prepared for cement hydration is absorbed by stone dust, as the result the available water for cement hydration is not enough. 


\section{References}

1. Turuallo, G., Sustainable Development of Concrete Using GGBS: Effect of Curing Temperatures on the Strength Development of Concrete. Applied Mechanics and Materials, 2015. 776: p. 6.

2. Joseph, P. and Tretsiakova, S., Sustainable Non-Metallic Building Materials. Sustainability, 2010. 2: p. 28.

3. Gautam, N., Krishna, V. and Srivastava, A., Sustainability in the Concrete Construction. International Journal of Environmental Research and Development, 2014. 4(1): p. 10.

4. Sakthivel, P. B., Ramya, C. and Raja, M., An Innovative Method of Replacing River Sand by Quarry Dust Waste in Concrete for Sustainability. International Journal of Scientific \& Engineering Research, 2013. 4(5): p. 4.

5. Turuallo, G., Early age strength development of ggbs concrete cured under different temperatures, in Engineering Department 2013, Liverpool University: United Kingdom.

6. Morbi, A., Cangiano, S. and Borgarello, E., Cement Based Materials for Sustainable Development, in Second International Conference on Sustainable Construction Materials and Technologies2010, Conventry University and The University of Wisconsin Milwaukee Centre for By-products Utilization: Ancona, Italy.

7. Mundra, S., et al., Crushed rock sand - An economical andecological alternative to natural sand tooptimize concrete mix. Perspectives in Science, 2016. 8: p. 2.

8. Allam, M. E., et al., Influence of Using of Granite Waste on the Mechanical Properties of Green Concrete ARPN Journal of Engineering and Applied Sciences, 2016. 11(5): p. 7.

9. Balamurugan, G. and Perumal, P., Behaviour of Concrete on the Use of Quarry Dust to Replace Sand - an Experimental Study Engineering Science and Technology: An International Journal, 2013. 4(6): p. 6.

10. Ashish, M. R., Ghogare, B. and Saklecha, P. P., Analysis and checking of stone dust as a replacement material of sand International Journal of Pure and Aplied Research in Engineering and Technology (IJPRET), 2015. 3(8): p. 9.

11. Karthick, J., Rama, T. and Bharathi, N. M., An Experimental Study on Usage of Quarry Rock Dust as Partial Replacement for Sand in Concrete. International Journal of Advanced Research in Education Technology, 2014. 1(1): p. 5.

12. Suman, B. K., Singh, A. K. and Srivastava, V., Stone Dust as Fine Aggregate Replacement in Concrete: Effect on Compressive Strength. International Journal of Advances in Engineering and Emerging Technology (IJAEET) 2015. 7(4): p. 5.

13. Suman, B. K. and Srivastava, V., Utilization of Stone Dust as Fine Aggregate Replacement in Concrete. Journal of Multidisciplinary Engineering Science and Technology (JMEST), 2015. 2(4): p. 5.

14. Abbas, S.Y., Srivastava, V. and Agarwal, V. C., Effect of Stone Dust on Compression Strength of Concrete - An Experimental Investigation. International Journal of Engineering Science and Research Technology, 2015. 4(2): p. 6.

15. Sankh, A. C., et al., Recent Trends in Replacement of Natural Sand with Different Alternatives. Journal of Mechanical and Civil Engineering, 2014: p. 8.

16. Shanmugapriya, T., K., Raja, K. S. and Balaji, C., Strength and durability properties of high strength performance concrete with manufactured sand. ARPN Journal of Engineering and Applied Sciences, 2016. 11(9): p. 10. 